7. Reprod. Fert. (1974) 38, 105-113

\title{
THE FERTILIZING CAPACITY OF BOAR SEMEN STORED IN THE PRESENCE OF GLYCEROL AT 20,5 AND $-79^{\circ} \mathrm{C}$
}

\author{
I. WILMUT* AND G. POLGE \\ A.R.C. Unit of Reproductive Physiology and Biochemistry, \\ 307 Huntingdon Road, Cambridge
}

(Received 8th August 1973)

\begin{abstract}
Summary. Three experiments have been carried out to investigate the mechanism by which glycerol reduces the fertilizing capacity of boar spermatozoa during storage, and any relationship between this effect and the relatively poor conception rates obtained with deep-frozen boar semen.

The loss of fertilizing capacity in the presence of glycerol was shown to be temperature-dependent. Fertilizing capacity was significantly reduced after $6 \mathrm{hr}$ of incubation at $20^{\circ} \mathrm{C}$ in the presence of 5 or $10 \%$ glycerol, although there was no detectable change in motility or morphology of the spermatozoa. By contrast, there was no effect on fertilizing ability after storage for $6 \mathrm{hr}$ at $5^{\circ} \mathrm{C}$ or for $30 \mathrm{~min}$ at $20^{\circ} \mathrm{C}$ in the presence of these concentrations of glycerol. Removal of the seminal plasma and a large proportion of the free cytoplasmic droplets did not prevent the reduction in fertilizing capacity. When semen was frozen and thawed, attempts to minimize the exposure of spermatozoa to glycerol did not lead to fertilization when the thawed semen was inseminated through the cervix. It is suggested that at ambient temperature glycerol causes damage to boar spermatozoa which is exacerbated by the stress of freezing and thawing.
\end{abstract}

\section{INTRODUCTION}

The inclusion of glycerol in diluents used for the storage of boar semen causes a reduction in conception rates (Polge, 1956, 1959; Settergren, 1958; King \& MacPherson, 1966; Graham, Rajammanan, Schmehl, Maki-Laurila \& Bower, 1971a). In the present paper, experiments are described which sought to determine the mechanism of the harmful effect of glycerol, and any relationship between this effect and the relatively poor conception rates which have been obtained with deep-frozen boar semen (Polge, 1956; Settergren, 1958; Pursel, Johnson \& Gerrits, 1969; Pursel \& Johnson, 1971).

* Present address: Animal Breeding Research Organisation, West Mains Road, Edinburgh EH9 3JQ. 


\section{MATERIALS AND METHODS}

Semen was collected from six boars (one Landrace, two Large White, one Large Black and two Large White $\times$ Essex) of proven fertility. The diluent used contained $2 \mathrm{~g}$ glycine, $0.242 \mathrm{~g}$ tris (hydroxymethyl) aminomethane and $25 \mathrm{ml}$ egg-yolk in $100 \mathrm{ml}$ diluent. The $\mathrm{pH}$ was adjusted to $7 \cdot 2$ with $\mathrm{HCl}$ and streptomycin sulphate and benzyl penicillin, 750 i.u. per ml, were added. When glycerol was included, it replaced water in the diluents. Estimates of the percentage of motile spermatozoa were made on thin semen smears, using a phase-contrast microscope fitted with a warm stage. The stage and all slides, coverslips and pipettes were warmed to $37^{\circ} \mathrm{C}$. Samples of the treated spermatozoa were fixed in buffered formol-saline (Hancock, 1957). Giemsa preparations were made by a modification of the method of Hancock (1952). If the semen had been diluted, it was necessary to remove egg-yolk and glycerol before making the smears. This step was achieved by fixing the sample in citrate buffer which contained $2 \%(\mathrm{v} / \mathrm{v})$ formaldehyde and carefully centrifuging and washing the spermatozoa. The spermatozoa were smeared on a clean slide, which was then dried at $37^{\circ} \mathrm{C}$ and left overnight in the Giemsa stain described by Hancock (1952).

Ovulation time in the experimental gilts was controlled by use of methallibure (Aimax, I.C.I. Ltd) and gonadotrophins, as described previously (Polge, Day \& Groves, 1968; Polge, Salamon \& Wilmut, 1970). Autopsy was carried out 8 to $10 \mathrm{hr}$ after ovulation and fertilization was assessed by examination of whole-mount preparations of the eggs. After fixation overnight in acetic alcohol (3:1, ethanol:acetic acid), the eggs were stained with $1 \%$ natural orcein in $45 \%$ aqueous acetic acid and examined with a phase-contrast microscope.

In Exp. 1, an examination was made of the effect of storage time, temperature and glycerol concentration on the fertilizing ability of the semen. Three concentrations of glycerol were used and the storage conditions were varied in three consecutive experimental groups. The concentrations of glycerol were 0,5 and $10 \%$ in the diluted semen. That volume of whole ejaculate which contained $1.0 \times 10^{10}$ spermatozoa was diluted to $50 \mathrm{ml}$ with glycine-yolk-tris diluent at $30^{\circ} \mathrm{C}$, before being allowed to cool to $20^{\circ} \mathrm{C}$. In Group 1, the diluted semen was cooled to $5^{\circ} \mathrm{C}$ over a 3-hr period before further dilution $(1: 1)$ with diluent containing glycerol. The semen was stored in the presence of glycerol for $6 \mathrm{hr}$ at $5^{\circ} \mathrm{C}$ before insemination. In Groups 2 and 3, the diluted semen was stored at $20^{\circ} \mathrm{C}$ for an equivalent 3-hr period before diluent which contained glycerol was added. In Group 2, the semen was stored in the presence of glycerol at $20^{\circ} \mathrm{C}$ for $6 \mathrm{hr}$ before insemination whereas in Group 3, insemination was completed within $30 \mathrm{~min}$ of the addition of diluent which contained glycerol. Insemination was carried out $30 \mathrm{hr}$ after the injection of HCG (Gestyl, Organon Ltd) and ovulation was expected to occur 40 to $42 \mathrm{hr}$ after this injection (Dziuk \& Baker, 1962). Each gilt was inseminated with $1.0 \times 10^{10}$ spermatozoa in $100 \mathrm{ml}$. A total of fifty-four gilts was used, eighteen in each group and six for each glycerol concentration. One ejaculate was used to inseminate a gilt in each of the three glycerol concentrations within one storage condition. 
There are potentially harmful enzymes in seminal plasma (Mann, 1964) and the cytoplasmic droplets contain many of the lysosomal enzymes (Dott \& Dingle, 1968; Allison \& Hartree, 1970). It is possible that glycerol renders the spermatozoa liable to attack by these enzymes.

A technique was employed in Exp. 2 by which the seminal plasma and a large proportion of the free cytoplasmic droplets were removed, and an estimate was made of the effect of glycerol on semen treated in this way. When the semen was collected for this experiment, the first sperm-rich fraction was collected into $800 \mathrm{ml}$ of a diluent which rapidly inhibited motility (Salisbury \& Graves, 1963). The collection was continued and the second ejaculatory wave was collected as whole semen. Centrifugation of the diluted semen at $600 \mathrm{~g}$ for $15 \mathrm{~min}$ induced good sedimentation of the spermatozoa while the droplets remained in suspension (Table 2). Control semen and the centrifuged sperm pellet were diluted with glycine-yolk-tris diluent to contain $1.0 \times 10^{10}$ spermatozoa in $50 \mathrm{ml}$. The partly diluted semen was incubated at $20^{\circ} \mathrm{C}$ for $3 \mathrm{hr}$ before dilution $1: 1$ with diluent containing $20 \%$ glycerol. Twelve gilts, six per treatment, were inseminated with control or centrifuged semen which had been stored for $6 \mathrm{hr}$ at $20^{\circ} \mathrm{C}$ in the presence of glycerol.

In Exp. 3, groups of gilts were inseminated with semen that had been frozen and thawed. The factors which were varied were: the time of insemination relative to ovulation, the temperature at which the diluent containing glycerol was added and the temperature at which the semen was stored after it had been thawed until it could be used for insemination. In Groups 1 and 4, the spermrich fraction was used while in the other groups whole ejaculate was used in an attempt to increase the number and concentration of the spermatozoa in the samples to be inseminated. Whole ejaculates were centrifuged at $500 \mathrm{~g}$ for 25 min, the plasma was removed and the sperm pellet was resuspended to a volu me of $40 \mathrm{ml}$ with glycine-yolk-tris diluent. The sperm-rich fraction was diluted $1: 1$ with diluent which did not contain glycerol. Final dilution (1:1) with diluent containing $15 \%$ glycerol was carried out at $20^{\circ} \mathrm{C}$ (Groups 1 and 4 ) or $10^{\circ} \mathrm{C}$ (Groups 2, 3, 5 and 6). One hour after dilution with diluent which contained glycerol, the diluted semen was placed in 2-ml ampoules and cooled at $1^{\circ} \mathrm{C}$ per min to $-10^{\circ} \mathrm{C}, 3^{\circ} \mathrm{C}$ per min from -10 to $-35^{\circ} \mathrm{C}$ and then quickly to $-79^{\circ} \mathrm{C}$. The semen was thawed by shaking the ampoules in water at $37^{\circ} \mathrm{C}$ and the ampoules were stored at $30^{\circ} \mathrm{C}$ (Groups $1,2,4$ and 5) or $10^{\circ} \mathrm{C}$ (Groups 3 and 6). When storage was to be at $10^{\circ} \mathrm{C}$, care was taken to transfer the ampoules to water at $10^{\circ} \mathrm{C}$ as the last ice disappeared. The interval between thawing and insemination was about $30 \mathrm{~min}$. Insemination was carried out either $16 \mathrm{hr}$ before (Groups 1, 2 and 3) or at the time of ovulation (Groups 4, 5 and 6) and all gilts were slaughtered $8 \mathrm{hr}$ after the expected time of ovulation.

The results of Exps 1 and 2 were treated by analysis of variance using weighted means. The percentages were converted to angles by the inverse sine transformation (Steel \& Torrie, 1960) and the means presented are the retransformed values. Some tables of results contain a record of 'number of eggs examined', and the difference between this number and the number of corpora lutea includes eggs not recovered, those that it was not possible to classify and those which were considered to be 'immature'. Of the 1049 eggs examined 
during these experiments, seventy were found to be immature $(6.67 \%)$. The occurrence of such eggs after gonadotrophin treatment has been noted previously (e.g. Spalding, Berry \& Moffit, 1955; Hunter, 1964, 1966).

\section{RESULTS}

\section{Experiment 1}

The effect of glycerol concentration on the fertilizing ability of semen stored at $20^{\circ} \mathrm{C}$ depended on the length of exposure of the spermatozoa to glycerol. The addition of 5 and $10 \%$ glycerol significantly reduced the proportion of eggs fertilized after a $6 \mathrm{hr}$ exposure to glycerol at $20^{\circ} \mathrm{C}$ (Table $1, P<0 \cdot 05$ ), whereas there was no effect of these concentrations in Group 3 when the spermatozoa were only exposed to glycerol for $30 \mathrm{~min}$. There was a non-significant tendency

Table 1. The effect of storage condition and glycerol concentration on the fertilizing capacity of boar semen

\begin{tabular}{|c|c|c|c|c|c|c|c|c|c|}
\hline \multirow[b]{2}{*}{$\begin{array}{l}\text { Glycerol concentration } \\
(\%) \\
\text { No. of ovulations } \\
\text { No. of eggs examined } \\
\text { No. of eggs fertilized } \\
\text { Percentage fertilized }\end{array}$} & \multicolumn{3}{|c|}{$\begin{array}{c}\text { Group } 1 \\
\text { (semen stored at } \\
\left.5^{\circ} \mathrm{C} \text { for } 6 \mathrm{hr}\right)\end{array}$} & \multicolumn{3}{|c|}{$\begin{array}{c}\text { Group } 2 \\
\text { (semen stored at } \\
\left.20^{\circ} \mathrm{C} \text { for } 6 \mathrm{hr}\right)\end{array}$} & \multicolumn{3}{|c|}{$\begin{array}{c}\text { Group } 3 \\
\text { (semen stored at } \\
20^{\circ} \mathrm{C} \text { for } 30 \text { min) }\end{array}$} \\
\hline & $\begin{array}{r}0 \\
76 \\
64 \\
26 \\
30.4\end{array}$ & $\begin{array}{c}5 \\
83 \\
71 \\
20 \\
22 \cdot 1\end{array}$ & $\begin{array}{c}10 \\
88 \\
70 \\
45 \\
71 \cdot 2\end{array}$ & $\begin{array}{r}0 \\
119 \\
84 \\
77 \\
91 \cdot 2\end{array}$ & $\begin{array}{c}5 \\
68 \\
54 \\
19 \\
32 \cdot 0\end{array}$ & $\begin{array}{c}10 \\
71 \\
48 \\
11 \\
34.9\end{array}$ & $\begin{array}{c}0 \\
84 \\
61 \\
51 \\
92 \cdot 4\end{array}$ & $\begin{array}{c}5 \\
73 \\
40 \\
23 \\
53 \cdot 6\end{array}$ & $\begin{array}{c}10 \\
87 \\
64 \\
48 \\
72 \cdot 9\end{array}$ \\
\hline
\end{tabular}

for $10 \%$ glycerol to increase the proportion of eggs fertilized after storage of the semen at $5^{\circ} \mathrm{C}$. After storage for $6 \mathrm{hr}$ at $20^{\circ} \mathrm{C}$, the proportion of motile spermatozoa was $75 \%$ (range 60 to $80 \%$ ) whereas after storage at $5^{\circ} \mathrm{C}$, the average was $60 \%$ (range 50 to $80 \%$ ). There was no effect of glycerol concentration on the percentage of motile spermatozoa. The only morphological change observed was swelling of a proportion of the acrosomes of spermatozoa which had been stored at $5^{\circ} \mathrm{C}$. There was no evidence of change due to the presence of glycerol, even after $6 \mathrm{hr}$ of storage at $20^{\circ} \mathrm{C}$ when the fertilizing ability of the spermatozoa was significantly reduced.

\section{Experiment 2}

The proportion of spermatozoa with droplets attached was rather high in both control and centrifuged samples, being $80 \%$ in one sample (Table 2). There was no apparent relationship between fertilizing ability and the proportion of spermatozoa with droplets attached. Whereas $63 \%$ of the free droplets could be identified in control samples, only $19 \%$ were present in centrifuged samples and it seems reasonable to assume that virtually all of the seminal plasma would be removed during the washing procedure.

There was no effect of partial removal of free droplets on the fertilizing capacity of spermatozoa stored at $20^{\circ} \mathrm{C}$ in the presence of $10 \%$ glycerol for $6 \mathrm{hr}$ (Table 3). The proportion of eggs fertilized was, however, rather higher than after the same treatment in Exp. 1. 
Table 2. The distribution of cytoplasmic droplets in control and centrifuged samples of boar semen

\begin{tabular}{|c|c|c|c|c|c|c|}
\hline \multirow[b]{2}{*}{ Boar } & \multicolumn{3}{|c|}{ Control } & \multicolumn{3}{|c|}{ Centrifuged } \\
\hline & $\begin{array}{l}\text { Spermatozoa } \\
\text { with droplets } \\
\text { attached }(\%)\end{array}$ & $\begin{array}{c}\text { Free } \\
\text { droplets/100 } \\
\text { spermatozoa }\end{array}$ & $\begin{array}{l}\% \text { free } \\
\text { droplets } \\
\text { present }\end{array}$ & $\begin{array}{l}\text { Spermatozoa } \\
\text { with droplets } \\
\text { attached }(\%)\end{array}$ & $\begin{array}{c}\text { Free } \\
\text { droplets } / 100 \\
\text { spermatozoa }\end{array}$ & $\begin{array}{l}\% \text { free } \\
\text { droplets } \\
\text { present }\end{array}$ \\
\hline $\begin{array}{l}\mathbf{A} \\
\mathbf{B} \\
\mathbf{B} \\
\mathbf{C}\end{array}$ & $\begin{array}{r}80 \\
40 \\
8 \\
30\end{array}$ & $\begin{array}{l}13 \\
39 \\
59 \\
41\end{array}$ & $\begin{array}{l}65 \\
65 \\
64 \\
59\end{array}$ & $\begin{array}{r}60 \\
10 \\
7 \\
53\end{array}$ & $\begin{array}{r}5 \\
18 \\
26 \\
7\end{array}$ & $\begin{array}{l}13 \\
20 \\
28 \\
15\end{array}$ \\
\hline Mean & 40 & 38 & 63 & 33 & 14 & 19 \\
\hline
\end{tabular}

\section{Experiment 3}

It was estimated that $20 \%$ of the spermatozoa which had been frozen and thawed were motile at the time of insemination so that the number of motile spermatozoa inseminated ranged from $5.4 \times 10^{9}$ to $1.0 \times 10^{10}$. A spermatozoon had penetrated the ooplasm and stimulated the resumption of meiosis in one

Table 3. The fertilizing capacity of control and centrifuged samples of boar semen after storage at $20^{\circ} \mathrm{C}$ in the presence of $10 \%$ glycerol for $6 \mathrm{hr}$

\begin{tabular}{l|c|c}
\hline & Control & Centrifuged \\
\hline No. of corpora lutea & 79 & 61 \\
No. of eggs & 56 & 44 \\
No. fertilized & 25 & 20 \\
Percentage fertilized & $40 \cdot 7$ & $44 \cdot 2$ \\
\hline
\end{tabular}

egg recovered from a gilt in Group 1 (Table 4). The sperm head was swollen and the meiotic spindle was in the second anaphase. No other egg had been penetrated nor were there any spermatozoa attached to or embedded in a zona pellucida. The number of spermatozoa found in the flushings from the oviducts was negligible.

Table 4. The fertilizing capacity of boar semen which had been frozen and thawed

\begin{tabular}{l|c|c|c|c|c|c}
\hline & $\begin{array}{c}\text { Group } \\
1\end{array}$ & $\begin{array}{c}\text { Group } \\
2\end{array}$ & $\begin{array}{c}\text { Group } \\
3\end{array}$ & $\begin{array}{c}\text { Group } \\
4\end{array}$ & $\begin{array}{c}\text { Group } \\
5\end{array}$ & $\begin{array}{c}\text { Group } \\
6\end{array}$ \\
\hline No. of gilts & 6 & 4 & 4 & 5 & 5 & 6 \\
Av. no. of sperm. inseminated $\times 10^{10}$ & $2 \cdot 7$ & $5 \cdot 0$ & $3 \cdot 2$ & $2 \cdot 8$ & $3 \cdot 9$ & $3 \cdot 1$ \\
Av. volume inseminated (ml) & 115 & 80 & 80 & 120 & 80 & 80 \\
No. of ovulations & 75 & 49 & 44 & 137 & 67 & 101 \\
No. of eggs examined & 63 & 38 & 28 & 78 & 45 & 71 \\
No. of eggs fertilized & 1 & 0 & 0 & 0 & 0 & 0 \\
\hline
\end{tabular}




\section{DISCUSSION}

In Exp. 1, the effect of glycerol on the fertilizing ability of boar spermatozoa varied with the length of exposure to glycerol and with temperature (Table 1). A similar temperature-dependent effect of glycerol on boar spermatozoa was noted during a study of motility, when it was found after storage for 4 days that glycerol improved motility at $5^{\circ} \mathrm{C}$, but clearly reduced the percentage of motile spermatozoa after storage at $15^{\circ} \mathrm{C}$ (Foote, Young, Turkheimer \& Bratton, 1959). There have been considerable variations in the results of experiments carried out to define the effect of glycerol on the fertilizing ability of boar spermatozoa. Successful results following long distance transport of boar semen have been achieved by incubation of the semen at $5^{\circ} \mathrm{C}$ in the presence of $5 \%$ glycerol for 45 to $76 \mathrm{hr}$. Twenty-one gilts were inseminated and fifteen of these farrowed (Niwa, Mizuho, Soejima \& Geing, 1964). By contrast, a study of the fertilizing ability of boar semen stored for up to $10 \mathrm{hr}$ at $7^{\circ} \mathrm{C}$ in the presence of $0,2,5$ or $7 \%$ glycerol revealed a lower conception ratio after storage of semen in the presence of 5 or $7 \%$ glycerol (Graham et al., 1971a). The variation in the results reflects differences in the number and concentration of spermatozoa which were inseminated. When large numbers were inseminated, there was no reduction in fertilizing capacity after storage at $5^{\circ} \mathrm{C}$ (Niwa et al., 1964; see also Table 1 in this paper), whereas when smaller numbers were inseminated a reduction in fertilizing capacity was apparent (Graham et al., 1971a).

The effect of glycerol on boar spermatozoa is clearly temperature-dependent. At $37^{\circ} \mathrm{C}$, boar spermatozoa are rapidly immobilized by glycerol whereas at $20^{\circ} \mathrm{C}$, motility is not affected as quickly but fertilizing capacity is lost within a few hours. At $5^{\circ} \mathrm{C}$, the loss of fertilizing capacity occurs over a longer period. By contrast, when bull semen is stored at $5^{\circ} \mathrm{C}$, incorporation of glycerol in the diluent increases the conception ratio (see Melrose, 1962).

The mechanism by which glycerol reduces the fertilizing capacity of boar spermatozoa is not known. As exposure to glycerol for $6 \mathrm{hr}$ at $5^{\circ} \mathrm{C}$ or for $30 \mathrm{~min}$ at $20^{\circ} \mathrm{C}$ did not cause a reduction in fertilization (Table 1 ), the reduction caused by exposure for $6 \mathrm{hr}$ at $20^{\circ} \mathrm{C}$ must involve action on the semen rather than on the female reproductive tract. It is probable that glycerol acts directly on the spermatozoa as removal of seminal plasma and a large proportion of the free cytoplasmic droplets did not prevent a reduction in fertilizing capacity (Table 3). No change, however, was detected in the motility or morphology of spermatozoa incubated for $6 \mathrm{hr}$ at $20^{\circ} \mathrm{C}$ in the presence of 5 or $10 \%$ glycerol, despite the fact that the fertilizing capacity of semen stored under these conditions was significantly reduced. Semen from the same boars was subjected to the treatments applied in Exp. 1 and spermatozoa were examined by electron microscopy (Jones, 1973). Changes were observed in the acrosomes of spermatozoa stored in the presence of 5 or $10 \%$ slycerol at $5{ }^{\circ} \mathrm{C}$, although the fertilizing capacity of semen stored under these conditions was not affected significantly. By contrast, no morphological change was detected which could be associated with the considerable loss of fertilizing ability of spermatozoa stored at $20^{\circ} \mathrm{C}$ in the presence of these concentrations of glycerol.

Inclusion of 5 to $10 \%$ glycerol in the medium causes a reduction in the 
motility and oxygen uptake of boar spermatozoa incubated at $37^{\circ} \mathrm{C}$ (Iida, 1964; Sanford, King \& MacPherson, 1972). Incubation of bull semen under these conditions caused a similar but smaller reduction in activity (Sanford et al., 1972). Addition of diluent containing glycerol to bull and boar semen disrupts the normal distribution of cations (Yassen \& Foote, 1967; Hood, Foley \& Martin, 1970) and causes loss of glutamicoxaloacetic transaminase (GOT) into the extracellular fluid (Crabo, Bower, Brown, Graham \& Pace, 1971). Loss of GOT from boar spermatozoa was more rapid when diluent which contained glycerol was added at $37^{\circ} \mathrm{C}$ than when it was added at $5^{\circ} \mathrm{C}$. The authors assumed that loss of GOT from the spermatozoa indicated the occurrence of damage to the cytoplasmic membrane.

Fowl spermatozoa in diluents which contain $5 \%$, or more, of glycerol are completely infertile when the semen is deposited in the vagina (Polge, 1951), although the fertilizing capacity is partly restored if the glycerol is removed by dialysis (Polge, 1951) or if the semen is deposited in the uterus (Allen \& Bobr, 1955). When the glycerol concentration is reduced rapidly in vitro, most fowl spermatozoa are killed and it has been suggested that similar damage might occur when the semen is deposited in the female reproductive tract (Polge, 1951). As the uterovaginal junction constitutes a barrier to the passage of spermatozoa in the chicken (Allen \& Bobr, 1955), it seems probable that the spermatozoa damaged by the rapid removal of glycerol in the vagina cannot pass into the uterus, whereas some of those damaged in the uterus can survive and achieve fertilization. It seems unlikely that penetration of glycerol into boar spermatozoa would be incomplete after $6 \mathrm{hr}$ at $5^{\circ} \mathrm{C}$ or $30 \mathrm{~min}$ at $20^{\circ} \mathrm{C}$, so the reduction in fertilizing ability after $6 \mathrm{hr}$ in the presence of 5 or $10 \%$ glycerol at $20^{\circ} \mathrm{C}$ could not be due entirely to damage caused by rapid removal of glycerol after insemination.

There was a marked contrast between the revival of about $20 \%$ of the frozen and thawed spermatozoa and the almost complete absence of fertilization in Exp. 3. Although autopsy was performed only $8 \mathrm{hr}$ after insemination, very few thawed spermatozoa were found in flushings from the region of the oviduct or the uterotubal junction; after the insemination of freshly collected semen considerable numbers of spermatozoa persist at the uterotubal junction for at least $24 \mathrm{hr}$ (Rigby, 1966).

The attempts in Exp. 3 to reduce the exposure of spermatozoa to glycerol at the higher temperatures which had been shown to be particularly damaging did not lead to fertilization. By contrast, a large proportion of the eggs were fertilized if the frozen and thawed semen was deposited in the oviduct (Polge et al., 1970) or if the final concentration of glycerol was reduced and the semen was deposited in the uterus (Wilmut \& Polge, 1971). Pregnancies have been obtained after insemination through the cervix of boar semen frozen and thawed by various methods (Crabo \& Einarsson, 1971; Graham et al., 1971a, b; Pursel \& Johnson, 1971.) There are considerable differences in the techniques employed, but all use relatively low concentrations of glycerol (0 to $3 \%$ ). Inclusion of higher concentrations of glycerol caused progressively greater damage to the acrosomal region of the spermatozoa (Wilmut \& Polge, 1971, 1972). It is possible that, as suggested by measurement of GOT release (Crabo 
et al., 1971), addition of diluent which contains glycerol causes slight damage to the cytoplasmic membranes before freezing and that this damage is exacerbated by the stresss of freezing and thawing. Although spermatozoa stressed in this manner can survive in the oviduct and achieve fertilization, they are not able to survive in the uterus or to pass from the uterus into the oviducts.

\section{ACKNOWLEDGMENT}

One of us (I.W.) gratefully acknowledges receipt of a post-graduate scholarship from the Meat and Livestock Commission.

\section{REFERENGES}

Allen, T. E. \& Bobr, L. W. (1955) The fertility of fowl spermatozoa in glycerol diluents after intrauterine insemination. Poult. Sci. 34, 1167.

Alrison, A. C. \& Hartree, E. F. (1970) Lysosomal enzymes in the acrosome and their possible rôle in fertilization. 7. Reprod. Fert. 21, 501.

Grabo, B. G., Bower, R. E., Brown, K. I., Graham, E. F. \& Pace, M. M. (1971) Extracellular glutamicoxaloacetic transaminase as a measure of membrane injury in spermatozoa during treatment. In Current Problems in Fertility, p. 33. Plenum Press, New York and London.

CRabo, B. G. \& Einarsson, S. (1971) Fertility in deep frozen boar spermatozoa. Acta vet. scand. 12, 125.

Dotт, H. M. \& Dingle, J. T. (1968) Distribution of lysosomal enzymes in the spermatozoa and cytoplasmic droplets of bull and ram. Expl Cell Res. 52, 523.

Dziuk, P. J. \& Baker, R. D. (1962) Induction and control of ovulation in swine. F. Anim. Sci. 21, 697.

Foote, R. H., Young, D. G., Turkheimer, A. R., \& Bratton, R. W. (1959) Collection, preservation and artificial insemination of boar semen. Annls Zootech. Series D, Suppl. 8, 27.

Graham, E. F., Rajammanan, A. H. J., Schmehl, M. K. L., Maki-Laurila, M. \& Bower, R. E. (1971a) Preliminary reports on procedure and rationale for freezing boar semen. A.I. Digest, $19,(1), 12$.

Graham, E. F., Rajammanan, A. H. J., Schmehl, M. K. L., Maki-Laurila, M. \& Bower, R. E. (1971 b) Fertility studies with frozen boar spermatozoa. A.I. Digest, 19, (6), 6 .

Hancock, J. L. (1952) The morphology of bull spermatozoa. F. exp. Biol. 29, 445.

Hancock, J. L. (1957) The morphology of boar spermatozoa. $7 l$ R. microsc. Soc. $76,84$.

Hood, R. D., Foley, C. W. \& Martin, T. G. (1970) Effects of cold shock, dilution, glycerol and dimethyl sulfoxide on cation concentration in porcine spermatozoa. F. Anim. Sci. 30, 91.

Hunter, R. H. F. (1964) Superovulation and fertility in the pig. Anim. Prod. 6, 189.

HunTER, R. H. F. (1966) The effect of superovulation on fertilisation and embryonic survival in the pig. Anim. Prod. 8, 457.

IIDA, I. (1964) Effect of glycerol on the oxygen uptake and metabolic utilisation by boar spermatozoa. Bull. Fac. Agric. Shizuoka Univ. 14, 11.

Jones, R. C. (1973) Changes occurring in the head of boar spermatozoa: vesiculation or vacuolation of the acrosome? F. Reprod. Fert. 33, 113.

King, G. J. \& MacPherson, J. W. (1966) Fertility of liquid boar semen. A.I. Digest, 14, (12), 6.

ManN, T. (1964) The Biochemistry of Semen and of the Male Reproductive Tract. Methuen, London.

Melrose, D. R. (1962) Artificial insemination in cattle. In The Semen of Animals and Artificial Insemination, pp. 1-181. Ed. J. P. Maule. Tech. Comm. No. 15 of Commonwealth Bureau of Animal Breeding and Genetics, Edinburgh.

Niwa, T., Mizuro, A., Soejima, A. \& Geing, N. (1964) Insemination trials with boar semen transported from Japan to Burma. Proc. 5th Int. Congr. Anim. Reprod. ES A.I., Trento, 4, 702.

Polge, G. (1951) Functional survival of fowl spermatozoa after freezing at $-79^{\circ} \mathrm{C}$. Nature, Lond. 167, 949.

Polge, C. (1956) Artificial insemination in pigs. Vet. Rec. 68, 62.

PoLge, C. (1959) Some experiments on the preservation of boar semen. Annls Zootech. Series D, Suppl. $8,113$.

Polge, C., Day, B. N. \& Groves, T. W. (1968) Synchronisation of ovulation and artificial insemination in pigs. Vet. Rec. 83, 136.

Polge, C., Salamon, S. \& Wilmut, I. (1970) Fertilising capacity of frozen boar semen following surgical insemination. Vet. Rec. $87,424$.

Pursel, V. G. \& Johnson, L. A. (1971) Procedure for the preservation of boar semen by freezing. U.S. Department of Agriculture Report, ARS 44-227. 
Pursez, V. G., Johnson, L. A. \& Gerrits, R. J. (1969) Fertility test of boar spermatozoa frozen by pellet method. F. Anim. Sci. 29, 196, Abstr.

RigBY, J. P. (1966) The persistence of spermatozoa at the uterotubal junction of the sow. J. Reprod. Fert. 11, 153.

Salisbury, G. W. \& Graves, G. W. (1963) Substrate-free epididymal-like bovine spermatozoa. $\mathcal{F}$. Reprod. Fert. 6, 351.

SANford, L. M., King, G. J. \& MacPherson, J. W. (1972) Influence of glycerol concentration and freezing to $-79^{\circ} \mathrm{C}$ on oxygen uptake and livability of boar and bull spermatozoa. Can. F. Anim. Sci. 52, 65.

Settergren, I. (1958) Experiments on the deep-freezing of boar semen at $-76^{\circ} \mathrm{C}$. Nord. Vet. Motet (Helsing fors) Sekt D. Rapp. 26.

Spalding, J. F., Berry, R. O. \& Mofrit, J. G. (1955) The maturation process of the ovum of swine during normal and induced ovulations. F. Anim. Sci. 14, 609.

Steel, R. G. D. \& Torrie, J. H. (1960) Principles and Procedures of Statistics. McGraw-Hill, New York and London.

Wilmut, I. \& Polge, C. (1971) Recent progress in the deep-freeze preservation of boar semen. $\mathcal{F}$. Reprod. Fert. 25, 301, Abstr.

Wilmut, I. \& Polge, C. (1972) The freezing of boar spermatozoa. Proc. 7th Int. Congr. Anim. Reprod. $\mathcal{G}$ A.I., Munich, 2, 1611 .

YASSEN, A. M. \& Foote, R. H. (1967) Sodium and potassium content of bull spermatozoa during processing prior to freezing. F. Anim. Sci. 26, 1104. 